\title{
Elemental Composition of Two Rice Cultivars under Potentially Toxic on Aquept and Aquent
}

\author{
Adesola Olutayo OLALEYE ${ }^{1)}$, Ayoade Olayiwola OGUNKUNLE ${ }^{1)}$, Baij Nath SINGH ${ }^{2}$, \\ Festus Olugbenga ODELEYE³), Oyeyemi Adigun DADA ${ }^{4}$, Bolarinwa Ayoola SENJOBI ${ }^{1)}$ \\ 1) Olabisi Onabanjo University Ago-Iwoye, Department of Soil Science and Farm Mechanisation, Nigeria; talk2yemyem@yahoo.com \\ 2) Birsa Agricultural University, Director of Agriculture, India \\ 3) University of Ibadan, Crop Protection and Environmental Biology, Ibadan, Nigeria \\ 4) Olabisi Onabanjo University Ago-Iwoye, Crop Production Department Nigeria \\ 5) University of Maiduguri, Department of Crop Production, Nigeria
}

\begin{abstract}
Iron toxicity is a major nutrient disorder affecting rice production of wetland rice in the irrigated and rain fed ecosystem in West Africa sub-region. Little attention has been paid to evaluating nutrient contents of rice cultivars grown on such soils and their relationship to the iron toxicity scores, grain yield and dry matter yields. A pot experiment was conducted on two potentially Fe-toxic soils (Aeric Fluvaquent and Aeric Tropaquept). The experiment was a $2 \times 2 \times 4$ factorial experiment, with three replicates arranged in a randomized model. The factors were two soil types, two rice cultivars ('ITA 212') and tolerant ('Suakoko 8') and four Fe 2+ levels (control, 1000, 3000 and $4000 \mathrm{mg} \mathrm{L-1)}$. The results showed that for both susceptible cultivar ('ITA 212') and the relatively tolerant ('Suakoko 8') cultivar, little or no differences were observed in their elemental composition regarding micro and macro-nutrients. For the susceptible cultivar, results showed that none of the tissue nutrients significantly relates to iron toxicity scores (ITS), grain yield and dry matter yield on both soil types. However, for the tolerant cultivar, ITS was observed to be significantly related to tissue K and P contents, on the two soil types respectively. Tissue $\mathrm{Ca}$ and $\mathrm{Mg}$ were observed to be significantly related to the dry matter yield (DMY) on Aeric Tropquept. It could be concluded that for these rice cultivars grown on two potentially Fe-toxic soils, different tissue nutrients may trigger the manifestation of bronzing or yellowing symptoms of rice cultivars.
\end{abstract}

Keywords: Rice, wetlands, iron toxicity, soil, yield, tissue nutrients

\section{Introduction}

Iron toxicity $(\mathrm{Fe})$ may be attributed to high iron content in the soil, low soil $\mathrm{pH}$ and soil fertility as well as by accumulation by of harmful organic acids and (or) hydrogen sulphide (Tanaka et al., 1966; Tanaka and Yoshida, 1970; Becker and Asch 2005). Plants generally show bronzing or yellowing symptoms if dissolved iron in the soil solution of the rhizosphere is in the 300 to $500 \mathrm{mg} /$ $\mathrm{kg}$ range. Excessive tissue Fe content ( $>300 \mathrm{mg} \mathrm{Fe} / \mathrm{kg}$ ) is known to be toxic to rice plants. It has been reported that rice plants grown on such soils show little or no differences in their elemental composition with regards to macro and micro-nutrients (Sahrawat et al., 1996; Olaleye et al., 2000; Sahrawat 2000, Olaleye et al., 2008; Olaleye and Ogunkunle, 2008). Little attention has been given to determining which of the macro and micronutrients significantly relates to the iron toxicity scores, grain and dry matter yields.
If iron toxicity expressed as bronzing or yellowing is indeed triggered by excessive $\mathrm{Fe}^{2+}$ uptake and insufficient supply of several nutrients, then it is expected that several tissue nutrients would be significantly related to the iron toxicity scores (ITS), grain yield (GY) and dry matter yield (DMY) of these two rice cultivars on two iron toxic soil types (Aeric Tropaquept and Aeric Fluvaquent). This hypothesis was tested by the study below.

\section{Materials and methods}

\section{Soils}

The Soil samples $(0-15 \mathrm{~cm}$ depth $)$ used for this investigation were randomly collected at C-Hydromorphic plot of the International Institute of Tropical Agriculture (IITA), Ibadan, Oyo State and Edozhigi, Niger State (representing humid forest and derived savannah agro-ecological zones respectively). The soil at Ibadan was classified as an Aeric Fluvaquent, whereas that in Niger State was classified as an 
Table 1. Results of multiple regression analysis of the tolerant check ('Suakoko 8') on Aeric Fluvaquent and Aeric Tropaquept

\begin{tabular}{|c|c|c|c|c|c|}
\hline \multicolumn{6}{|c|}{ Aeric Fluvaquent } \\
\hline \multicolumn{6}{|c|}{ Independent variable $=$ ITS } \\
\hline Regression & $\mathrm{DF} \neq$ & Sum of Squares & Mean squares & $\mathrm{F}$ & Prop $>$ F $\dagger$ \\
\hline Error & 1 & 2.634 & 2.634 & 7.28 & 0.022 \\
\hline \multirow[t]{2}{*}{ Total } & 10 & 3.616 & 0.362 & & \\
\hline & 11 & 6.250 & & & \\
\hline Variables & Parameter estimate & Standard error & Type II sum of squares & $\mathrm{F}$ & Prop $>\mathrm{F} \dagger$ \\
\hline $\mathrm{K}$ & -1.127 & 0.417 & 2.634 & 7.28 & 0.022 \\
\hline \multicolumn{6}{|c|}{ Aeric Tropaquept } \\
\hline \multicolumn{6}{|c|}{ Independent variable $=$ ITS } \\
\hline Regression & $\mathrm{DF} \neq$ & Sum of Squares & Mean squares & $\mathrm{F}$ & Prop $>\mathrm{F} \dagger$ \\
\hline Error & 1 & 1.723 & 1.723 & 3.81 & 0.079 \\
\hline \multirow[t]{2}{*}{ Total } & 10 & 4.527 & 0.453 & & \\
\hline & 11 & 6.250 & & & \\
\hline Variables & Parameter estimate & Standard error & Type II sum of squares & $\mathrm{F}$ & Prop $>\mathrm{F} \dagger$ \\
\hline Intercept & 3.671 & 1.004 & 6.056 & 13.38 & 0.004 \\
\hline $\mathrm{P}$ & -13.515 & 6.927 & 1.723 & 3.81 & 0.079 \\
\hline \multicolumn{6}{|c|}{ Aeric Tropaquept } \\
\hline & & Independent $\mathrm{v}$ & $=$ Dry matter yield (DMY) & $\mathrm{R}^{2}=0.559$ & \\
\hline Regression & $\mathrm{DF} \neq$ & Sum of Squares & Mean squares & $\mathrm{F}$ & Prop $>\mathrm{F} \dagger$ \\
\hline Error & 2 & 2523.102 & 1261.551 & 5.70 & 0.025 \\
\hline \multirow[t]{2}{*}{ Total } & 9 & 1990.718 & 221.191 & & \\
\hline & 11 & 4513.820 & & & \\
\hline Variables & Parameter estimate & Standard error & Type II sum of squares & $\mathrm{F}$ & Prop $>\mathrm{F} \dagger$ \\
\hline $\mathrm{Ca}$ & -73.713 & 22.190 & 2440.860 & 11.04 & 0.01 \\
\hline $\mathrm{Mg}$ & 143.387 & 60.345 & 1248.841 & 5.65 & 0.04 \\
\hline
\end{tabular}

₹ $\mathrm{DF}=$ degrees of freedom; $\uparrow$ Level of significance $\mathrm{P}=0.05 \%$;

Aeric Tropaquept (Olaleye, 1998). Soil samples were composited, air-dried and representative samples were taken for laboratory analysis after being crushed to pass a 2-mm sieve and some to further pass a $0.5-\mathrm{mm}$ sieve. Detailed soil analytical procedures were followed as described by Olaleye et al. (2000). Selected chemical properties of the soils are presented in Fig 1.

\section{Iron studies}

Four iron (Fe) levels (control, 1000, 3000 and 4000mg Fe $\mathrm{L}^{-1}$ ) were prepared from $\mathrm{FeSO}_{4}$, to be used with two rice cultivars ('ITA 212' and 'Suakoko 8'). The former variety was susceptible whereas the latter was relatively tolerant to $\mathrm{Fe}^{2+}$ toxicity.

\section{Pot experiment.}

The experiment was a $2 \times 2 \times 4$ factorial experiment with three replicates in arranged in a randomized fashion. The factors were two soil types, two rice cultivars and four $\mathrm{Fe}^{2+}$ levels (control, 1000, 3000 and $4000 \mathrm{mg} \mathrm{L}^{-1}$ ). Soils (4 $\mathrm{kg}$ ) were placed in 5-liter plastic pots and were thoroughly mixed with a basal fertilizer application. In the Aeric Fluvaquent (Derived Savannah), the fertilizers were applied at the rates of 560-mg N/pot, 48- $\mathrm{mg}_{2} \mathrm{O}_{5} /$ pot, $100-\mathrm{mg} \mathrm{K}_{2} \mathrm{O} /$ pot and 26-mg Zn /pot whereas in the Aeric Tropaquept
(Humid forest), 560-mg N/pot, 200- $\mathrm{mg} \mathrm{P}_{2} \mathrm{O}_{5} /$ pot and 26$\mathrm{mg} \mathrm{Zn} \mathrm{/pots} \mathrm{were} \mathrm{applied.} \mathrm{Standing} \mathrm{water} \mathrm{of} \mathrm{about} \mathrm{2-3-cm}$ depth was maintained throughout the crop growth. The water used for irrigation was de-ionized water of good quality having $\mathrm{pH}$ ranging between 6.8 and 7.1. Seedlings of about 23 day-old of uniform vigor were transplanted at the rate of four seedlings/pot into the reduced soils where Fe treatments were introduced a week after transplanting.

\section{Plant samplings}

Plant samples with different degrees of bronzing symptoms were scored redundant visually using a scale of 1-9 based on the International Rice Research Institute (IRRI) standard evaluation systems for rice (IRRI 1988). A score of 1 suggests normal growth and tillering, while a score of 9 indicated that almost all plants are dead/dying. Plant samplings were carried-out per pot/treatment at 3060 and 90 days after transplanting (DAT). They were washed with $0.1 \%$ teepol solution to avoid contamination especially of Fe and were then rinsed with de-ionized water. The washed plant samples were oven-dried at a temperature of $65^{\circ} \mathrm{C}$ for 12 hours, cut and ground using mortal and pestle for easy digestion by a concentrated double acid (2:1 nitric and perchloric acids) mixture. Detailed methodology is described elsewhere (Olaleye et al., 2000). 
48

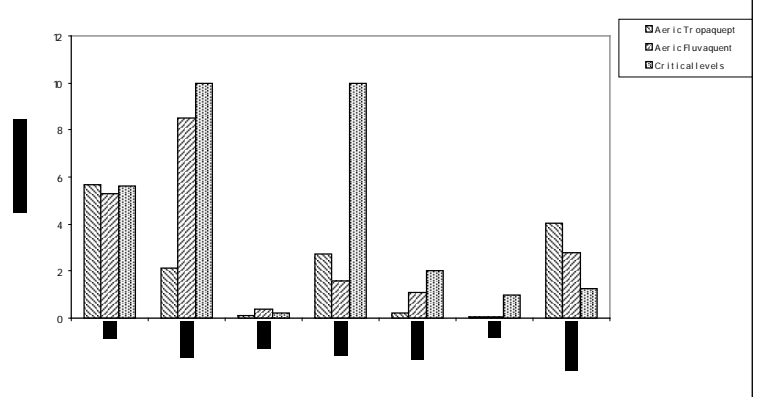

Fig. 1.Important soil chemical properties of iron toxic soils

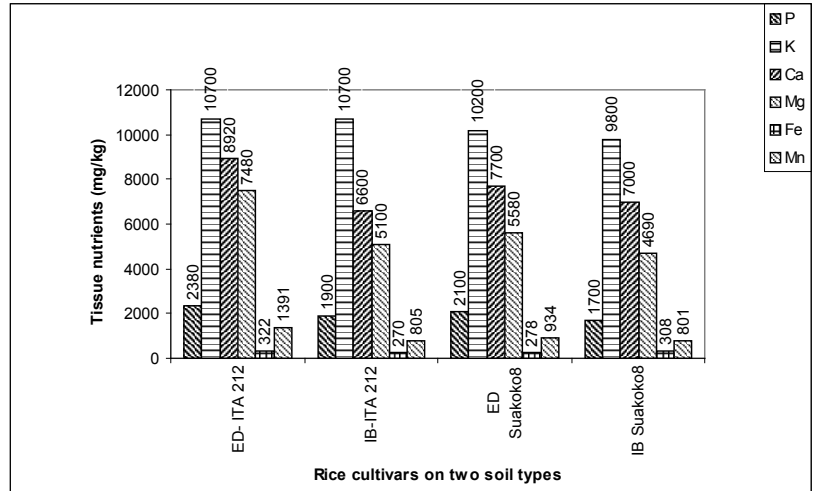

Fig. 2. Tissue nutrient contents in two rice cultivars on two soil types

\section{Dry matter and Grain yield}

The crops were harvested when most of the panicles turned yellow. The grain yield (GY) and dry matter yield (DMY) were recorded.

\section{Statistical Analysis}

Multiple regression analysis was used to evaluate which tissue nutrient contents (dependent variables) significantly relate to ITS, GY and the DMY (independent variables) at $\mathrm{P}=0.05 \%$ using SAS (SAS Inst., 1996).

\section{Results and discussion}

The soil chemical properties of the two soils are low when compared with the critical values (Tanaka and Yoshida 1970;Senadhira 1994 and Sahrawat et al., 1997) (Fig 1$)$. The active Fe content $(\mathrm{FeH})$ is very high compared with the critical level of $1.25 \%$ (Singh, 1992). This showed that these soils are potentially very iron toxic. The mean tissue nutrient contents showed that no apparent differences exist in the two rice cultivars on both soil types (Fig 2.). Tissue Fe content in both rice cultivars was observed to be in excess of $300 \mathrm{mg} / \mathrm{kg}$ (i.e. in the toxic range). This was in agreement with the results of Fageria and Rabelo, (1987); Sahrawat et al. (1996); Olaleye et al. (2000) and Sahrawat, (2000) and Olaleye et al., 2009.
The mean iron toxicity scores (ITS), grain yield (GY) and dry matter yield (DMY) are presented in Fig. 3. The tolerant cultivar ('Suakoko 8') out-yielded the susceptible check on both soil types in terms of GY (g/pot). Furthermore, results showed that the DMY was much affected by the $\mathrm{Fe}^{2+}$ levels on both soil types. This was in agreement with the findings of Fageria and Rabelo, (1987) and Olaleye and Ogunkunle, (2008). In addition, the mean ITS ranged between 2.25 and 2.50, though low, the mean tissue Fe contents ranged between 270 and $322 \mathrm{mg} \mathrm{Fe} \mathrm{kg}^{-1}$ dry weight.

The result of step-wise multiple regression analysis is presented in Tab 1. For the susceptible check ('ITA 212') grown on both soil types, none of the tissue nutrients significantly relates to ITS, GY and DMY at $\mathrm{P}=0.05 \%$. However, on Aeric Fluvaquent, the ITS of a tolerant check ('Suakoko 8') was observed to be significantly related to tissue $\mathrm{K}$ content $(\mathrm{P}=0.02 \%)$. The regression equation is given as: ITS $=3.109-1.13(\mathrm{~K}), \mathrm{R}^{2}=0.421$. Similarly, on both soil types, results showed that none of the tissue nutrients significantly relates to GY and DMY on Aeric Fluvaquent. However, on Aeric Tropaquept, the ITS of a tolerant cultivar (Sukoko 8) appeared to be significantly related to the tissue $\mathrm{P}$ content, but the $\mathrm{R}^{2}=0.276$ appeared to be low. . In addition, on the same soil type, of the entire yield attributes (GY and DMY), only the DMY appeared to be significant related to tissue $\mathrm{Ca}$ and $\mathrm{Mg}$ with $\mathrm{R}^{2}=0.559$.

The results of the regression analysis still points to the fact that deficiencies of $\mathrm{P}$ and $\mathrm{K}$ in both soil solution and tissues, may trigger bronzing symptoms of rice cultivars grown such soils. This was in agreement with the result of earlier authors that deficiencies of $\mathrm{P}, \mathrm{K}, \mathrm{Zn} \mathrm{Ca}$, and $\mathrm{Mg}$ in relation to $\mathrm{N}$ would result in excessive $\mathrm{Fe}^{2+}$ uptake (Benckiser $e$ al. 1984a; Benckiser et al. 1984b and Olaleye et al. 2000; Olaleye et al., 2009). The importance of P, K and Ca has been demonstrated to improve the oxidizing capacity of rice roots and thus increase its iron excluding capacity rice roots (Wyn Jones and Lunt, 1967).

\section{Conclusions}

The results of this study clearly show that soil type significantly influence tissue nutrient contents of rice cultivars grown on it. The bronzing symptoms of some rice cultivars on two soil types is a function of different tissue nutrient contents, in this case, $\mathrm{K}$ and $\mathrm{P}$ contents for the tolerant cultivar ('Suakoko 8').

\section{Acknowledgments}

This work was conducted with the financial support of African Development Bank (ADB) and West Africa Rice Development Association (WARDA) through a research fellowship to A. O. Olaleye. We also thank member of staff of the Analytical Service Laboratory (ASL), IITA, Ibadan, 
Nigeria for permission to use their laboratory for soil and plant analyses.

\section{References}

Benckiser, G., J. C. G. Ottow, I. Watanabe and S. Santiago (1984b). The mechanisms of excessive iron-uptake (iron toxicity) of wetland rice. J. Plant Nutr. 7:177-185.

Benckiser, G., S. Santiago, H. U. Neue, I. Watanabe and J. C. G. Ottow (1984a). Effect of fertilization on exudation, dehydrogenase activity, iron-reducing populations and $\mathrm{Fe}$ (II)-formation in the rhizosphere of rice (Oryza sativa L.) in relation to iron toxicity. Plant and soil. 79:305-316.

Fageria, N. K. and N. A. Rabelo (1987). Tolerance of rice cultivars to Iron toxicity. J. Plant Nutr. 10(6):653-661.

International Rice Research Institute (IRRI) (1988). Standard evaluation system for rice. International Rice Research Institute, Los Banos, Philippines.

Olaleye, A. O., F. O. Tabi, A. O. Ogunkunle, B. N. Singh and K. L. Sahrawat (2000). The effect of toxic iron concentration on the growth of lowland rice. J. Plant Nutr. USA. Article accepted on the $22^{\text {nd }}$ May 2000. 24 Issue 2.

Olaleye, A. O., A. O. Ogunkunle and K. L. Sahrawat (2000). Forms and pedogenetic distribution of extractable iron in selected wetland soils in Nigeria. Commun. Soil Sci. and Plant Anal. 31(7-8):923-941.

Olaleye, A. O. (1998). Characterization, evaluation, nutrient dynamics and rice yield of selected wetland soils in Nigeria. Ph.D. Thesis, University of Ibadan. p. 205.
Sahrawat, K. L., C. K. Mulbah, S. Diatta, R. D. Delaune, W. H. Patrick Jr, B. N. Singh and M. P. Jones (1996). The role of tolerant genotypes and plant nutrients in the management of iron toxicity in lowland rice. J. Agric. Sci. 126, 143-149.

Sahrawat, K. L, M. P. Jones, and S. Diatta (1997). Extractable phosphorus and rice yield in an Ultisol of the humid forest zone in West Africa. Commun. Soil Sci. Plant Anal. 28:(910):711-716.

Sahrawat, K. L. (2000). Elemental composition of rice plants as affected by iron toxicity under field conditions. Commun. Soil Sci. Plant Anal. 31 (17-18):2819-2827.

Statistical Analysis Systems (SAS) Institute Inc. (1996). SAS User's guide: statistics. Version 6th Edition. Cary, North Carolina.

Singh, B. P. (1992). Characteristics of Fe-toxic soils and affected plants and their correction in acid Haplaquents of Mehalaya. IRRI News 2(2):18-19.

Tanaka, A. and S. Yoshida (1970). Nutritional disorders of the rice plant in Asia. Int. Rice Res. Inst. Tech. Bull. p. 10-51.

Tanaka, A. R., R. Loe and R. Navasero (1966). Some mechanisms involved in the development of iron toxicity symptoms in the rice plant. Soil Sci. Plant Nutr. 12:158164.

Tanaka, A. and S. Yoshida (1970). Nutritional disorders of the rice plant in Asia. IRRI Technical Bull. 10. IRRI Manila Phillipines.

Wyn, J., R. G. and O. R. Lunt (1967). The function of Calcium in plants. Bot. Rev. 33:407-426. 